\title{
Pemanfaatan Internet Sebagai Sumber Informasi Kesehatan Bagi Masyarakat
}

\author{
Retasari Dewi, Preciosa Alnashava Janitra, Nindi Aristi \\ Fakultas Ilmu Komunikasi, Universitas Padjadjaran \\ Email: retasari.dewi@unpad.ac.id
}

\begin{abstract}
Abstrak
Tujuan dari kegiatan "Penyuluhan Literasi Digital: Pemanfaatan Internet Sebagai Sumber Informasi Kesehatan Bagi Masyarakat Desa Tarumajaya, Kecamatan Kertasari, Kabupaten Bandung" ini adalah guna mengetahui media apa saja yang dapat digunakan oleh masyarakat desa Tarumajaya dalam pencarian informasi kesehatan dan bagaimana masyarakat desa mengelola media dalam pencarian informasi kesehatan. Sejumlah 48 orang masyarakat desa yang terdiri dari ibu PKK dan aparatur desa mengikuti kegiatan penyuluhan ini. Penyuluh yang terlibat berasal dari Fakultas Ilmu Komunikasi Universitas Padjadjaran yang memiliki keahlian dibidang penyuluh literasi digital. Metode penyuluhan yang digunakan adalah metode ceramah, diskusi dan permainan. Hasil dari kegiatan penyuluhan ini adalah peserta sudah aktif menggunakan mesin pencarian secara daring untuk berbagai informasi, peserta juga mengenal aplikasi percakapan daring dan beberapa diantaranya telah memiliki akun media sosial Facebook dan Instagram. Dengan adanya penyuluhan ini peserta dibekali pengetahuan dan tips untuk mengkritisi sebuah informasi kesehatan yang mereka peroleh di internet serta ciriciri informasi bohong (hoax).
\end{abstract}

Kata kunci: Hoaks, informasi kesehatan, literasi digital, pencarian informasi.

\begin{abstract}
The purpose of the activity "Digital Literacy Counseling: Utilization of the Internet as a Source of Health Information for the People of Tarumajaya Village, Kertasari District, Bandung Regency" is to find out what media can be used by Tarumajaya villagers in seeking health information and how the village community manages the media in health information search. A total of 48 villagers consisting of PKK mothers and village officials attended this extension activity. The extension officers involved came from the Faculty of Communication, Padjadjaran University, who have expertise in the field of digital literacy counselors. The extension method used is lecture, discussion and game methods. The results of this extension activity are that participants have been active using online search engines for various information, participants also know about online conversation applications and some of them already have Facebook and Instagram social media accounts. With this extension, participants were provided with knowledge and tips to criticize the health information they obtained on the internet and hoax information.
\end{abstract}

Keywords: Hoaxes, digital literacy health information, information retrieval. 


\section{Pendahuluan}

Literasi digital merupakan konsep yang terkait erat dengan perkembangan media digital, terutama dari segi efek atas konsumsi media tersebut. Saat ini, isu literasi digital telah mengemuka dan menjadi kajian penting dalam berbagai bidang ilmu. The European Commission Joint Research Center menyatakan bahwa literasi digital merupakan hal yang esensial untuk perkembangan pembelajaran seumur hidup (lifelong learning) (Lynch, 2017). Mengingat pemanfaatan media digital yang semakin meluas di berbagai bidang kehidupan dan lapisan masyarakat. Kemudahan pemanfaatan teknologi digital seharusnya dibarengi dengan kesiapan dan kesadaran masyarakat dalam menggunakan teknologi informasi.

Literasi dapat diartikan sebagai 'melek', dalam arti yang ketat mengacu pada kemampuan untuk membaca dan memahami teks (O'Donahoe dan Tynana, 1998). Literasi juga dapat dipahami sebagai kemampuan untuk menghasilkan, memahami dan menggunakan teks dalam cara yang sesuai dengan kebudayaan (membudaya). O'Donahue dan Tynana juga menyebutkan definisi lain tentang literasi yaitu sebagai seperangkat keterampilan dan kompetensi, yang menuju pada pertimbangan perannya dalam praktek sosial.

Intergrasi media ke dalam kehidupan sehari-hari, disadari atau tidak, menyebabkan ketergantungan, sehingga khalayak harus lebih berhati-hati dalam menggunakannya. Disinilah literasi digital menjadi penting, dengan tujuan mengembangkan pribadi otonom yang disebut juga kompetensi media. Gapski dan Gehrke menjelaskan, kompetensi media adalah kemampuan individu untuk melihat dunia secara kritis, reflektif dan independen, serta bertanggung jawab menggunakan media sebagai sarana ekspresi kreatif (Iriantara, 2009).

Berdasarkan hasil survey yang dilansir oleh Asosiasi Penyelenggara Jasa Internet Indonesia (APJII) tahun $2017,54,68 \%$ dari total populasi penduduk Indonesia atau sejumlah 143,26 juta orang telah menggunakan internet (Asosiasi Penyelenggara Jasa Internet Indonesia, 2017). Jumlah ini terus meningkat dari tahun ke tahun. Salah satu data yang disurvey APJII adalah mengenai pemanfaatan internet di bidang kesehatan. Ternyata 51,06\% responden menyatakan menggunakan internet untuk mencari informasi kesehatan dan sebanyak 14,05\% responden melakukan konsultasi dengan ahli kesehatan.

Kesehatan merupakan aset yang penting bagi seorang individu, tidak heran jika mereka mereka melakukan berbagai cara untuk menjaga kesehatan atau mendapatkan kesehatannya kembali. Sekarang ini dengan adanya teknologi, informasi kesehatan dapat diakses dari 'genggaman tangan.' Untuk mengetahui informasi tentang penyebab dan gejala sebuah penyakit masyarakat dapat mengakses mesin pencari dari mengetik kata kunci. Seorang pasien dapat berkonsultasi dengan 
Retasari Dewi : Pemanfaatan Internet Sebagai Sumber Informasi Kesehatan Bagi Masyarakat

dokter tanpa harus bertemu tatap muka, menunggu antrian yang panjang serta membayar mahal, cukup melalui aplikasi konsultasi kesehatan.

Isu kesehatan adalah isu yang cukup seksi karena banyak dicari masyarakat. Sehingga beberapa pihak yang tidak bertanggung jawab banyak menggunakannya untuk hal negative. Seorang wartawan senior dari Persatuan Wartawan Indonesia, Wina Armada Sukardi, melakukan sebuah penelitian. Dari sekitar seribu berita kebohongan, 27\% dijadikan Sukardi sebagai sampel dan akan diperiksa kebenarannya. Dari sampel tersebut, berita kebohongan yang paling banyak ditemukan adalah informasi kesehatan. Seperti yang dikutip dari Tirto.id, Wina menjelaskan bahwa penyebar berita kebohongan ini merasa informasi tersebut bermanfaat dan harus segera diberitahukan kepada orang lain dan tidak memiliki niat buruk (Hasan, 2017).

Studi lain terkait media informasi kesehatan juga dapat dilihat dari penelitian Prasanti (2017) berjudul "Potret Media Informasi Kesehatan Bagi Masyarakat Urban di Era Digital," menyimpulkan bahwa masyarakat urban menggunakan media online berupa situs yang dirasa kredibe; sebagai sumber informasi kesehatan utamanya. Sedangkan media sosial (aplikasi Whatsapp, dll) dan media elektronik (televisi) hanya dijadikan sebagai media pendukung. Pada masyarakat urban sudah ada kesadaran untuk tidak mudah percaya pada informasi kesehatan yang datang begitu saja di media digital. Hal ini menyebabkan media yang digunakan untuk mencari informasi kesehatan semakin bervariasi (Prasanti, 2017).

Mengingat betapa mudahnya akses dan penggunaan internet, sehingga pemanfaatannya tidak hanya milik masyarakat urban. Masyarakat rural-urban dan rural pun turut serta menikmati berbagai informasi yang ada di internet. Dari survey APJII juga diketahui bahwa hampir setengah masyarakat kabupaten $(49,49 \%)$ dan desa (48,25\%) menggunakan internet (Asosiasi Penyelenggara Jasa Internet Indonesia, 2017).

Pelatihan ini ingin mengajarkan bagaimana pemanfaatan media dalam pencarian informasi bagi masyarakat Desa Tarumajaya. Tujuannya adalah supaya mereka tidak semata-mata tergantung pada media tanpa mengkritisinya. Selain itu, jiks media massa dipergunakan untuk mengisi waktu luang, sebagai sarana eskapisme, maka, khalayak dapat memanfaatkannya lebih bijak.

Sehingga, diperlukan adanya kegiatan yang menciptakan kesadaran khalayak akan pentingnya literasi digital. Penyediaan pusat literasi digital di masa depan akan diperlukan dan penting demi mewujudkan masyarakat yang sadar media.

Dilihat dari segi definisinya, istilah "literasi" sendiri telah mengalami perkembangan. Pada awalnya, literasi diartikan sebagai kemampuan untuk membaca dan menulis. Sejalan dengan apa yang dinyatakan oleh United Nation Educational, Scientific and Cultural Organization berikut ini, 
"The most common understanding of literacy is that it is a set of tangible skills particularly the cognitive skills of reading and writing - that are independent of the context in which they are acquired and the background of the person who acquires them" (UNESCO, 2006)

Literasi melibatkan perolehan keterampilan dan pengetahuan untuk membaca, menginterpretasikan, memproduksi teks dan artefak, serta untuk mendapatkan alat intelektual serta kapasitas agar dapat berpartisipasi secara penuh dalam suatu budaya dan masyarakat (Macedo, 2007). Literasi digital berbeda dengan literasi media karena karakteristik medianya yang juga berbeda, Karena itu sebelum membahas lebih lanjut tentang literasi media digital, perlu dibahas mengenai istilah "media digital" itu sendiri.

Di era digital di mana generasi millennial lahir dan tumbuh, media pun telah bermetamorfosis, sehingga pendekatan literasi media yang digunakan turut beradaptasi. Saat ini literasi media tidak hanya mencakup literasi atas media massa konvensional (tradisional) atau komunikasi melalui media massa, literasi juga perlu dilakukan pada komunikasi dengan media berbasis digital. Media digital adalah berbagai metode penyimpanan, penyampaian (transmisi) dan manipulasi data dalam bentuk digital.

Melalui definisi media digital dan media baru yang telah dipaparkan maka konsep literasi pun perlu disesuaikan sehingga kemudian muncul istilah literasi digital. Secara luas, menurut Gilster, digital literacy dapat dikonsepsikan sebagai kemampuan untuk memahami dan menggunakan informasi dalam beragam format dari sumber yang jangkauannya luas saat dihadirkan melalui komputer (Lankshear and Knobel, 2008)

Dalam konteks penyuluhan ini, literasi dilihat sebagai alat yang dapat digunakan dalam memanfaatkan media secara lebih positif dan optimal, terutama ketika mengkonsumsi konten kesehatan. Fokusnya adalah meminimalisir efek negatif dari media serta mencegah konsumsi atas konten tersebut. Berdasarkan paparan tersebut, maka rumusan pada kegiatan pengabdian ini adalah bagaimana literasi digital bagi masyarakat Desa Tarumajaya Kecamatan Kertasari, Kabupaten Bandung?

\section{Metode}

Kegiatan pelaksanaan literasi digital bagi masyarakat Desa Tarumajaya, dilakukan dengan mempertimbangkan materi pelatihan, khalayak yang dihadapi, masalah yang berkembang serta lingkungan yang mendukung. Model pembelajaran yang digunakan dalam kegiatan ini adalah andragogi karena para peserta merupakan orang dewasa yang dilibatkan ke dalam struktur 
Retasari Dewi : Pemanfaatan Internet Sebagai Sumber Informasi Kesehatan Bagi Masyarakat

pengalaman belajar. Terkait model tersebut, maka kegiatan ini menggunakan beberapa metode berikut:

1. Ceramah dan tanya jawab, metode ini digunakan untuk memberi wawasan kepada masyarakat desa tentang kemampuan penggunaan media. Metode ini bersifat interaktif sehingga masyarakat difasilitasi juga untuk dapat mengemukakan pertanyaan-pertanyaan terkait materi yang disampaikan atau mengomentarinya. Untuk mendukung sesi ceramah dan tanya jawab ini, tim penyuluh menggunakan proyektor yang menampilkan slide dan ilustrasi terkait materi

2. Diskusi, metode ini digunakan untuk menghimpun pengalaman serta pendapat masyarakat terkait dengan perkembangan gadget dan pencarian informasi di internet. Melalui proses ini maka masyarakat difasilitasi untuk mengemukakan pandangannya atau memiliki sikap terhadap lingkungannya terutama terkait isu kesehatan di media digital.

Keberhasilan penyuluhan ini dilihat berdasarkan hasil pre-test dan post-test yang dilakukan terhadap para peserta. Pre-test dilakukan dalam bentuk pemberian pertanyaan langsung terkait isu-isu hoaks kesehatan di media serta jenis media digital yang dapat menjadi sumber informasi kesehatan. Setelah penyuluhan berlangsung, post-test dilakukan dalam bentuk kuis, metode ini digunakan untuk menarik perhatian audiens dan mengecek pemahaman peserta pada materi yang telah disajikan. Peserta yang berhasil menjawab pertanyaan diberikan hadiah. Peserta pada umumnya dapat menjelaskan kembali pemahaman mereka tentang pemanfaatan internet sebagai sumber informasi kesehatan. Mereka juga dapat menyebutkan macam-macam media yang dapat digunakan sebagai alternatif untuk mencari informasi kesehatan.

\section{Hasil dan Pembahasan}

Desa Tarumajaya, kecamatan Kertasari, Kabupaten Bandung, Provinsi Jawa Barat adalah desa yang terkenal dengan keindahan danaunya, yaitu Situ Cisanti. Berada sekitar 60 km dari Kota Bandung, Desa Tarumajaya memiliki potensi berupa lahan perkebunan teh, kina, kehutanan, pertanian dan juga peternakan. Memiliki luas wilayah $2.743 \mathrm{Ha}$ dan jumlah penduduk sebanyak 13.986 jiwa (Tryana, 2017). Desa Tarumajaya juga merupakan salah satu desa peternakan di Kabupaten Bandung yang menjadi penghasil susu sapi.

Walau potensi sumber daya alam yang besar, namun dominasi profesinya mayoritas warganya adalah buruh tani. Menurut Ayi Iskandar, Kepala Desa Tarumajaya, rendahnya penghasilan warga perkapital dikarenakan keuntungan hasil tani banyak diambil oleh bandar atau tengkulak. 
Retasari Dewi : Pemanfaatan Internet Sebagai Sumber Informasi Kesehatan Bagi Masyarakat

Berdasarkan hasil pengamatan kami APBDesa Tarumajaya sebagian besar masih diperuntukan untuk pembangunan fisik. Sedangkan pembangunan masyarakat hanya sekitar $20 \%$ dari total belanja desa.

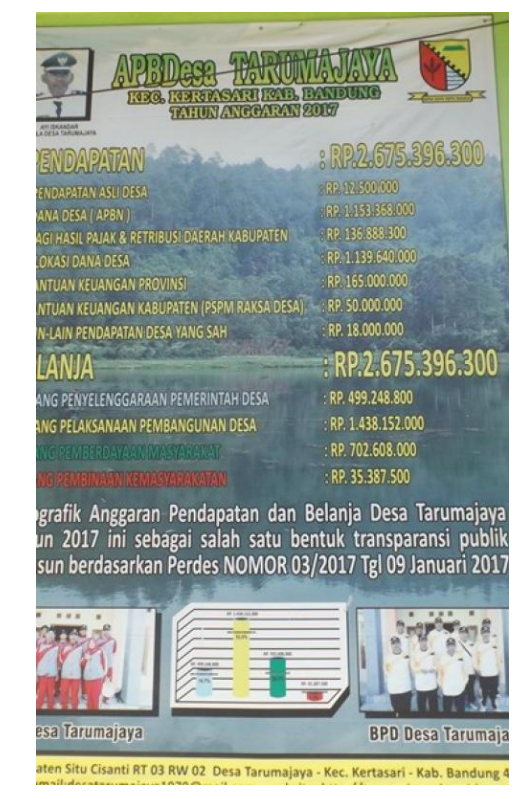

Gambar 1. APB Desa Tarumajaya

Kecamatan Kertasari Kabupaten Bandung (Tryana, 2017)

Sebagai desa yang tengah berkembang, pemberdayaan masyarakat dan pembinaan kemasyarakatan harus juga menjadi prioritas pemerintah desa. Tidak adanya pembinaan yang terorganisir terkait penyuluhan petanian dan petenakan menyebabkan masih tergantungnya petani dan peternak dengan bandar. Kurangnya pembinaan pada warga terkait pariwisata, menjadikan perkembangan daerah wisata tidak terorganisir. Akibatnya, keberadaan potensi yang seharusnya dapat meningkatkan penghasilan warga, menjadi tidak optimal.

Kepedulian pemerintah desa pada bidang kesehatan juga belum optimal, karena masih tergantung dengan program-program dari pemerintah pusat. Perlu diketahui bahwa Situ Cisanti yang menjadi ikon Desa Tarumajaya merupakan hulu dari Sungai Citarum, sungai terbesar dan terkotor di Jawa Barat. Pembenahan dan revitalisasi sungai Citarum harus dimulai dari hulunya yaitu Situ Cisanti.

Berdasarkan hasil observasi peneliti dengan warga Desa Tarumajaya pengetahuan warga terkait menjaga kebersihan dan kesehatan terutama untuk warga di hulu sungai didapat dari sumber yang terbatas yaitu petugas Puskesmas. Sumber informasi kesehatan yang lain mereka dapatkan dari mesin pencari di internet. Sebagian besar warga memang telah menggunakan telepon pintar (smartphone). Mereka menggunakan secara pribadi ataupun berbagi penggunaannya dengan anak dan suami. Peserta sudah akrab dengan penggunaan aplikasi percakapan daring yaitu Whatsapp. 
Retasari Dewi : Pemanfaatan Internet Sebagai Sumber Informasi Kesehatan Bagi Masyarakat

Beberapa dari mereka juga menggunakan aplikasi media social seperti Facebook dan Instagram. Untuk pencarian informasi beberapa warga mengaku sering menggunakan mesin pencarian informasi dari Google.

Warga mengetahui bahwa di internet kerap beredar berita bohong atau lebih dikenal dengan istilah hoax, namun warga tidak dapat membedakan mana berita yang bohong atau berita yang benar. Seperti beberapa informasi kesehatan yang beredar secara viral terkait penyebab kanker serviks dan pertolongan pertama pada penderita struk.

Berdasarkan hasil observasi tersebut, penyuluhan literasi digital terkait pemanfaatan internet sebagai sumber informasi kesehatan bagi masyarakat dirasa perlu dilakukan. Penyuluhan ini dilakukan oleh tim yang juga berpengalaman sebagai komunikator literasi digital dan komunikasi kesehatan. Sebelum acara dimulai, peserta diminta melakukan registrasi terlebih dahulu. Acara dibuka oleh Tim Penyuluh dengan melakukan tanya jawab untuk menguji pengetahun warga tentang internet dan pemanfaatannya.

Dari pretest tersebut diketahui bahwa warga banyak mendapat informasi kesehatan dari media sosial facebook dan pesan dari whatsapp. Beberapa warga mengaku pernah ikut membagikan kembali informasi kesehatan yang dia dapatkan tanpa mengecek kebenaran informasi tersebut terlebih dahulu pada petugas kesehatan. Sebagian besar warga tidak mengetahui ciri-ciri informasi bohong dan tidak mengetahui bagaimana mencari informasi kesehatan dari sumber yang dapat dipercaya.

Tabel 1. Data Usia Peserta PenyuluhanLiterasi Digital

\begin{tabular}{ccc} 
& \multicolumn{1}{c}{ USIA } & Jumlah \\
\hline 1 & 15 s.d 30 tahun & 4 \\
\hline 2 & 31 s.d 45 tahun & 23 \\
\hline 3 & 46 s.d 60 tahun & 20 \\
\hline 4 & $>60$ tahun & 1 \\
\hline & JUMLAH & 48
\end{tabular}

Peserta penyuluhan literasi digital berjumlah 48 orang, yang terdiri dari 40 orang perempuan dan 8 orang laki-laki. Peserta terdiri dari ibu PKK dan aparat desa Tarumajaya. Usianya beragam dari 25 hingga diatas 60 tahun. Pada dasarnya penyuluh tidak membatasi jenis kelamin maupun usia dari peserta penyuluhan, namun menurut keterangan aparat desa audiens perempuan lebih mudah dijangkau karena kebanyakan warga berjenis kelamin laki-laki bekerja, dan masyarakat usia remaja dan anak-anak sekolah. Pekerjaan peserta penyuluhan sebagian besar adalah ibu rumah tangga/tidak bekerja, sisanya pedagang, petani, dan Pegawai Negeri Sipil (PNS). 
Retasari Dewi : Pemanfaatan Internet Sebagai Sumber Informasi Kesehatan Bagi Masyarakat

Tabel 2. Data Pendidikan Terakhir Peserta Penyuluhan Literasi Digital

\begin{tabular}{clc} 
No & \multicolumn{1}{c}{ Pendidikan Terakhir } & Jumlah \\
\hline 1 & $\begin{array}{l}\text { Rendah (Tidak tamat SD, SD, dan } \\
\text { SLTP) }\end{array}$ & 26 \\
\hline 2 & Tinggi (SLTA, Akademi) & 22 \\
\hline & JUMLAH & 48
\end{tabular}

Materi penyuluhan diberikan oleh Nindi Aristi, M.Comn. Peserta penyuluhan yang hadir diinformasikan mengenai apa itu internet dan bagaimana internet telah menjadi bagian dari keseharian kehidupan sebagian besar warga negara Indonesia. Pemateri juga berbagi informasi mengenai layanan apa yang paling banyak diakses dan informasi yang paling banyak dicari oleh warganet adalah informasi kesehatan. Peserta yang hadir menyimak dengan seksama sambil sesekali berkomentar pada materi yang disampaikan. Warga kemudian diajak mengkritisi jika memang sumber informasi kesehatan mereka berasal dari internet bagaimana jika mereka tidak terliterasi atau melek media. Otomatis warganet tidak bisa membedakan informasi kesehatan yang benar atau yang bohong. Untuk itu pemateri memberi tahukan ciri-ciri berita bohong dan tips untuk mengkritisi berita bohong.

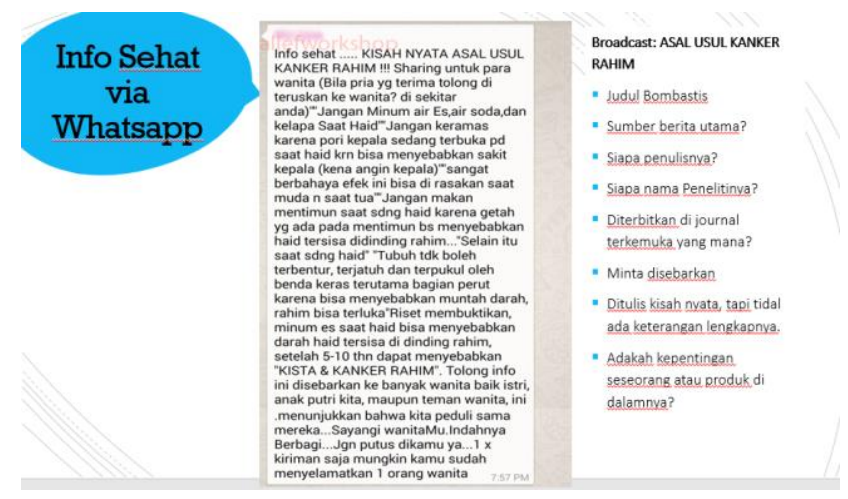

Gambar 2. Contoh Informasi kesehatan hoaks yang beredar di Whatsapp

Beberapa ciri yang bisa peserta amati dari berita hoax yang sering beredar di whatsapp atau media sosial, yaitu: memiliki judul yang bombastis, sumber berita utama atau penulis utamanya tidak diketahui. Biasanya disebutkan juga hasil penelitian, tapi tidak dijelaskan siapa nama penelitinya dan telah diterbitkan di jurnal ilmiah yang mana. Informasi hoax juga seringkali minta disebarkan lagi, dengan kata-kata yang persuasif. 


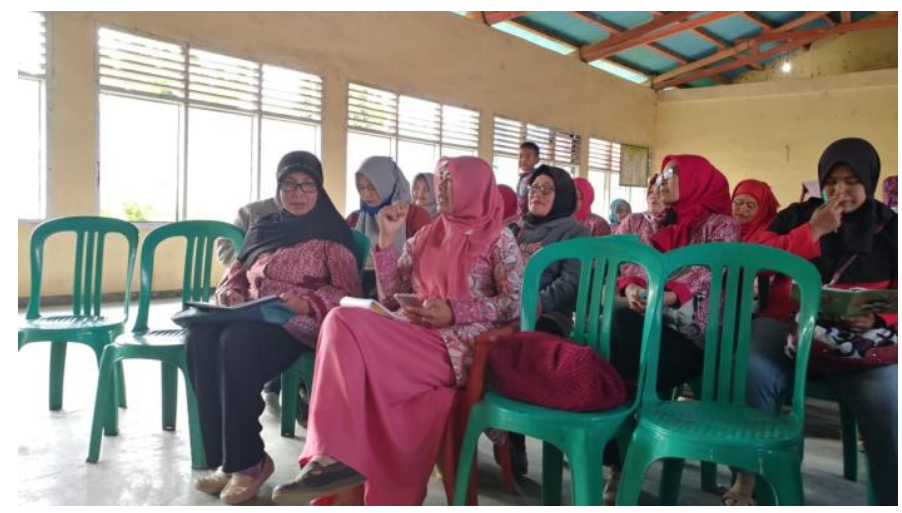

Gambar 3. Peserta penyuluhan saat sesi diskusi dan tanya jawab

Setelah pemaparan materi, warga kemudian diajak berdiskusi dan membagikan pengalaman terkait pemanfaatan internet untuk pencarian informasi kesehatan. Tim penyuluh juga mengadakan kuis sebagai indikator apakah terdapat peningkatan pengetahuan peserta terkait pencarian informasi kesehatan di internet, peserta menjadi lebih tertarik mengetahui lebih lanjut bagaimana memanfaatkan internet untuk mencari informasi kesehatan yang benar, dan apakah peserta penyuluhan akan menginformasikan hasil pembelajaran hari ini pada keluarga dan warga masyarakat lain. Pada sesi ini diketahui bahwa terdapat peningkatan pengetahuan warga mengenai ciri dari berita hoaks dan bagaimana mencari sumber informasi yang kredibel di internet. Peserta juga mengatakan akan lebih berhati-hati dan tidak langsung menyebarkan informasi yang mereka dapatkan tanpa mencari tahu kebenarannya terlebih dahulu.

\section{Simpulan}

Kepedulian pemerintah terkait literasi digital terutama pemanfaatannya sebagai sumber informasi di kawasan pedesaaan dirasa masih kurang, padahal dengan berkembangnya teknologi informasi dan komunikasi, internet telah menjangkau kedesa-desa terutama di Jawa Barat. Kegiatan penyuluhan literasi digital yang dilaksakan pada hari Selasa, 31 Juni 2018 di Ruang Serbaguna Desa Tarumajaya Kecamatan Kertasari Kabupaten Bandung Provinsi Jawa Barat berlangsung lancar. Para audiens berpartisipasi aktif dalam sesi materi maupun tanya jawab.

Kegiatan penyuluhan literasi digital untuk pemanfaatan internet sebagai sumber informasi kesehatan sebenarnya tidak hanya tertuju pada masyarakat desa usia dewasa. Karena pengguna internet tidak terbatas pada usia dewasa tapi juga warga desa usia sekolah yang dikenal juga dengan istilah generasi Z. Perlu adanya kegiatan penyuluhan lanjutan yang terorganisisr dari berbagai pihak mengenai penyaringan konten negatif yang ada di internet dan pemanfaatan internet untuk kegiatan kewirausahaan yang mendatangkan keuntungan untuk meningkatkan kesejahteraan warga. 


\section{Ucapan Terima kasih}

Kegiatan pelatihan komunikasi ini merupakan bagian dari program Hibah Internal Unpad, yang diinisiasi oleh Universitas Padjadjaran. Kegiatan ini terselenggara berkat kerjasama antara dosen, mahasiswa dan masyarakat. Untuk itu tim penulis mengucapkan terima kasih dan apresiasi kepada pemerintah Desa Tarumajaya Kecamatan Kertasari Kabupaten Bandung yang telah memberikan berbagai kemudahan dalam pelaksanaan kegiatan ini. Kepada kader PKK Desa Tarumajaya. Ucapan terima kasih juga disampaikan kepada para mahasiswa yang telah menjadi fasilitator pada kegiatan penyuluhan ini.

\section{Daftar Pustaka}

Asosiasi Penyelenggara Jasa Internet Indonesia (APJII). (2017). Infografis: Penetrasi dan Perilaku Pengguna Internet Indonesia. Jakarta: APJII.

Hasan, A. M. (2017, Mei 1). Kesehatan. Retrieved from Tirto.id: https://tirto.id/info-hoax-soalkesehatan-paling-banyak-beredar-di-masyarakat-cnQZ

Horrigan, J. (2016). Digital Readiness Gaps. Pew Research Center.

Lynch, M. (2017, December 30). Digital Literacy is The Most Important Lifelong Learning Tool. Retrieved from The Tech Edvocate: https://www.thetechedvocate.org/digital-literacyimportant-lifelong-learning-tool/

Prasanti, D. (2017, Desember). Potret Media Informasi Kesehatan Bagi Masyarakat Urban di Era Digital. IPTEK-KOM, 19(2), 149-162.

Roosdhani, Mohamad Rifqy, Purwo Adi Wibowo dan Anna Widiastuti. (2012). Analisis Tingkat Penggunaan Teknologi Informasi dan Komunikasi pada Usaha Kecil Menengah di Kabupaten Jepara. Jurnal Dinamika Ekonomi dan Bisnis Vol. 9 No. 2 Oktober 2012

Widyanti, Ari dan Indryati Sunaryo. (2016). Intervensi Kognitif dan Pendekatan Rantai Nilai dalam Peningkatan Pemanfaatan Teknologi Informasi dan Komunikasi Di Usaha Kecil dan Menengah di Bandung. Jurnal Teknik Industri, Vol. XI, No. 2, Mei 2016

Lankshear, Colin and Michele Knobel (ed).2008. Digital Literacies: Concepts, Policies and Practices. New York: Peter Lang

Macedo, Donaldo Pereira. 2007. Media Literacy: A Reader. New York: Peter Lang

UNESCO. 2006. Education for All Global Monitoring Report: Literacy for Life. Paris: United Nations Educational, Scientific and Cultural Organization

e-Marketer. (2016, April 30). indonesia is the 3rd largest smartphone market in the asia pacific. Retrieved January 10, 2017, from indonesia-investments.com: HYPERLINK "http://www.indonesia-investments.com/news/todays-headlines/indonesia-is-the3rd-largestsmartphone-market-in-the-asia-pacific/item6777" http://www.indonesiainvestments.com/news/todays-headlines/indonesia-is-the3rd-largest-smartphone-market-inthe-asia-pacific/item6777? 
Retasari Dewi : Pemanfaatan Internet Sebagai Sumber Informasi Kesehatan Bagi Masyarakat

Tryana, Henry. (2017). Profil Desa Tarumajaya. Retrieved Juli 10, 2018, from Desa Tarumajaya: "https://www.tarumajaya.desa.id/" 